\title{
K vývoji vzdělanostní struktury žáků středního a vyššího vzdělávání
}

\author{
JiŘí VojtĚch, Martin Úlovec
}

\begin{abstract}
Abstrakt: Text popisuje vývoj vzdělanostni struktury a zmény v podilu žáků vstupujicich do stredního a vyššího odborného vzdělávání. K popisu vzdělanostni struktury a jejího vývoje využivá relativni četnosti, které jsou z hlediska postiženi dynamiky a zmèn systému relevantnějši než absolutni četnosti. Východiskem je populační vývoj v $\check{C} R$ a jeho souvislost s vývojem rozděleni žákù do jednotlivých kategorii vzdèláni. Kromè národni úrovně postihuje i pohled na problematiku v krajském měritku. Dále se vènuje vývoji počtu absolventů a souvisejicim problémưm. Ze srovnánís dalšimi evropskými zemèmi vyplývá, že má ČR nejvy̌ši zastoupeni žákủ v technických oborech a nejnižši podil gymnazistü. Podily jednotlivých kategorii vzdèlání jsou v ČR pomèrnè stabilní, zamèstnavatelé však pocituji nedostatek kvalifikované pracovni sily. Hlavni pričiny jsou demografický pokles a predčasné odchody ze vzděláváni. Ty predstavuji velké riziko z hlediska sociálni koheze, protože mladi lidé se základnim vzdělánim, bez kvalifikace, jsou ohroženi opakovanou, dlouhodobou nezamèstnanosti se v̌̌emi negativni dopady v oblasti sociálně patologických jevi̊.
\end{abstract}

Kličová slova: vzdělanostni struktura, kategorie vzděláni, vzděláni s výučním listem, maturitní obory v odborném vzdèláváni, maturitni obory zahrnujici odborný výcvik, gymnaziálni vzdèláváni, nástavbové studium, vy̌ši odborné vzděláváni, demografický pokles, kvalifikovaná pracovni síla.

\section{PopulaČní VÝVOJ 15LeTÝCH v ČESKÉ REPUBLICE}

Vzdělanostní struktura žáků středního vzdělávání je daná rozdělením žáků základních škol do jednotlivých kategorií středního vzdělávání. V českém vzdělávacím systému si žáci vstupující do středního vzdělávání mohou dlouhodobě vybírat mezi všeobecnou př́pravou $\mathrm{v}$ kategorii gymnaziálního vzdělávání $(\mathrm{K})$ a mezi kategoriemi odborného vzdělávání. ${ }^{1}$ Ty

\footnotetext{
${ }^{1}$ Zákon č. 561/2004 Sb. (školský zákon) rozlišuje pouze tři stupně vzdělání: a) střední vzdělání, b) střední vzdělání $s$ výučním listem a c) stř̌ední vzdělání s maturitní zkouškou. Dále pak ve středním vzdělání s maturitní zkouškou rozlišuje vzdělávací programy šestiletého nebo osmiletého gymnázia, vzdělávací programy v délce 4 let denní formy vzdělávání a vzdělávací programy nástavbového studia v délce 2 let denní formy vzdělávání. Podrobnější rozčlenění do kategorií vzdělání je jako přehled uvedeno v nařízení vlády č. 211/2010 Sb., o soustavě oborů vzdělání v základním, středním a vyšším odborném vzdělávání. K identifikace kategorie slouží písmeno a někdy i následující číslice v kódu oboru vzdělání.
} 
tvoří: střední vzdělání $s$ výučním listem (E a H), střední vzdělání (bez výučního listu a maturitní zkoušky - C a J), střední vzdělání s maturitní zkouškou (odborné M), střední vzdělávání s maturitní zkouškou zahrnující i odborný výcvik (L0) a nástavbové studium (L5). ${ }^{2}$

Vývoj vzdělanostní struktury podle kategorií vzdělání je možné sledovat podle počtu žáků a dále podle jejich podílu na celku žáků, kteří přicházejí do středního vzdělání ze základní školy nebo přecházejí z nižšího stupně gymnaziálního vzdělávání.

Sledování údajů o vývoji počtu žáků je v situaci výrazné proměnlivosti počtu 15letých v př́slušných populačních ročnících málo funkční, protože po téměr tř̌i desetiletí docházelo $\mathrm{k}$ jejich výraznému poklesu, a nelze tedy dobře srovnávat vývoj mezi jednotlivými kategoriemi. Porovnávání proto provádíme především na základě podílů nově prijiímaných.

Podívejme se tedy nejprve na situaci vývoje počtu 15 letých, což je věk, ve kterém by převážná část žáků základních škol měla přecházet do středního vzdělávání.

Již od roku 1989 byl v podstatě trvalým jevem pokles počtu žáků přicházejících do středních škol. Pokles nebyl rovnoměrný. K prvnímu výraznému poklesu došlo v letech 1989-1997. Po určité stabilizaci v letech 1998-2009 došlo v dalších letech opět $\mathrm{k}$ výraznému poklesu počtu 15letých a tedy $\mathrm{k}$ poklesu nově přijímaných do středních škol.

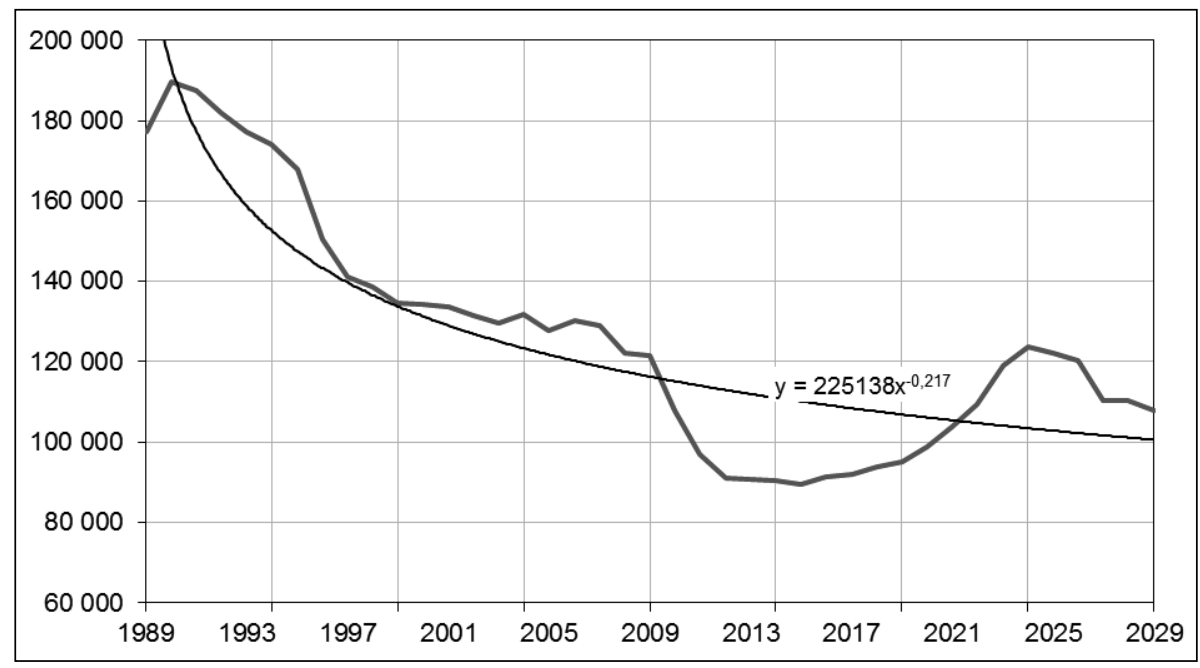

Obr. 1. Dlouhodobý vývoj počtu 15letých osob v České republice (zdroj dat: ČSÚ, www.czso.cz)

\footnotetext{
${ }^{2}$ Podrobnějš́ informace o charakteristikách jednotlivých kategorií vzdělání jsou dostupné na www.infoabsolvent.cz/obory/1 nebo in Vojtěch \& Chamoutová (2018).
} 
Teprve školní rok 2017/2018 přinesl změnu, konečně začal nárůst počtu žáků vstupujících do prvních ročníků středních škol, i když tento nárůst byl zatím nepatrný (129 žáků; 0,1 \%). Počet 15letých dosáhl minima již v roce 2015, v počtech žáků přicházejících do středních škol se však nárůst 15letých ihned neobjevil. Bylo to způsobeno jednak odklady při nástupu do prvních tříd základní školy, jednak neúspěšností některých žáků v průběhu základní školy, posunem mezi kalendářním a školním rokem, ale i skutečností, že vzhledem k velkému zájmu zaměstnavatelů o pracovní sílu zůstala část žáků se základním vzděláním na trhu práce jako nekvalifikovaná pracovní síla.

Průběh vývoje počtu 15letých na obrázku 1 ukazuje postupný mírný nárůst $\mathrm{v}$ dalších letech, poté i výraznější vzestup, v celku lze očekávat necelé desetiletí nárůstu počtu přijímaných. I tak ale počet 15letých nepřesáhne hranici 120 tisíc a v dalším vývoji bude opět docházet $\mathrm{k}$ poklesu.

V souvislosti s poklesem počtu žáků v populačních ročnících se objevily prognózy o možném přsunu většiny nově príijímaných do maturitních oborů a tím i o výrazném omezení podílu žáků $\mathrm{v}$ učňovském školství. Zdůrazňování potřebnosti a uplatnitelnosti vyučených absolventů i podpora formou stipendií či jiných výhod ovlivňuje žáky a jejich rodiče a podíl nově prijiatých do učebních oborů je v podstatě stabilní. Zároveň je ale zřejmé, že vli- vem populačního poklesu nejsou a nebudou pro trh práce $\mathrm{k}$ dispozici takové počty pracovníků, které by v plné míre početně nahradily odcházející do důchodu.

\section{VÝVOJ VZDĚLANOSTNÍ \\ STRUKTURY V ČLENĚNÍ PODLE \\ KATEGORIÍ VZDĚLÁNí}

K porovnávání vývoje vzdělanostní struktury považujeme za vhodné použít procentuální rozdělení proudu žáků přicházejících do jednotlivých kategorií stř̌edního vzdělávání (nově přijatí do 1 . ročníků a přecházející do vyššího stupně gymnaziálního studia $\left.{ }^{3}\right)$. Někdy uváděné celkové počty žáků $v$ jednotlivých kategoriích jsou ovlivněny různou délkou studia, počty či podíly absolventů pak předčasnými odchody ze vzdělávání a neúspěšností u jednotné části maturitní zkoušky.

Vývoj podílu žáků vstupujících do oborů poskytujících vzdělání $s$ výučním listem (kategorie $\mathrm{H}+\mathrm{E}$ ) doznal v posledním desetiletí určitých změn. Až do roku 2008 jejich podíl klesal (30,3 \%), v roce 2008/209 došlo k obratu a tento podíl trvale mírně narůstal, až v roce 2012/2013 dosáhl v tomto desetiletí maxima (32,1\%). Potom následoval opět mírný pokles a v roce 2017/2018 je podíl žáků přijatých do učebních oborů $29,33 \%$, tedy nepatrně pod $30 \%$.

\section{V „klasických“ maturitních obo-} rech v odborném vzdělávání (katego-

\footnotetext{
${ }^{3}$ Do víceletých gymnázií vstupují žáci po 5 . nebo 7. ročníku základní školy, pro korektní srovnání, odpovídající stejnému populačnímu ročníku, zahrnujeme tyto žáky v době, kdy by vstupovali do středního vzdělávání po absolvování základního vzdělání, tedy započítáváme žáky vstupující do 5. a 3. ročníku víceletých gymnázií.
} 
rie M) dochází v tomto desetiletí ke kolísání - po nárůstu do roku 2009/2010 až na hodnotu 36,9 \% následoval pokles až do roku 2013/2014 (34,8\%), pak opět mírný nárůst, $s$ malým propadem $\mathrm{v}$ roce 2015/2016. Současná hodnota podílu žáků přijatých do maturitních oborů odborného vzdělání bez odborného výcviku $37,2 \%$ představuje maximum desetiletí. Zajímavou skupinu oborů, která je formálně zařazována do kategorie $\mathrm{M}$, tvoří obory lyceí. Svou koncepcí se nacházejí mezi odbornými maturitními obory kategorie $\mathrm{M}$ a obory gymnázií. Jsou charakterizovány poměrně širokou odbornou prýípravou, zároveň se podílem všeobecného vzdělání blíží gymnáziím. Poskytují tedy prvotně př́ípravu na přechod do terciárního vzdělání, ovšem směrovanou na jeho určité sektory (technický, ekonomický, zdravotnický ad.). Podíl žáků lyceí v posledním roce činil 3,9\%.

$\mathrm{V}$ maturitních oborech zahrnujících odborný výcvik (kategorie L0) dochází od roku $2008 \mathrm{k}$ poklesu, $\mathrm{v}$ posledním roce tvoř́i podíl přijatých žáků $6,1 \%$. I tak jde o nezanedbatelný podíl, přesahující $6 \%$ nově přijatých. Žáci této formy vzdělání absolvují i odborný výcvik, a to prakticky ve stejném rozsahu jako žáci v tř́letých učebních oborech, a jsou připravováni jako vysoce kvalifikovaní pracovníci pro náročná dělnická nebo službová povolání. Rostoucí náročnost mnoha dělnických profesí i povolání ve službách často vyžaduje vzdělání na vyšší úrovni, proto má toto vzdělání důležité místo ve vzdělávacím sytému. V současné době je pokusně ověřována možnost získat $\mathrm{v}$ maturitních oborech kategorie L0 ve třetím ročníku

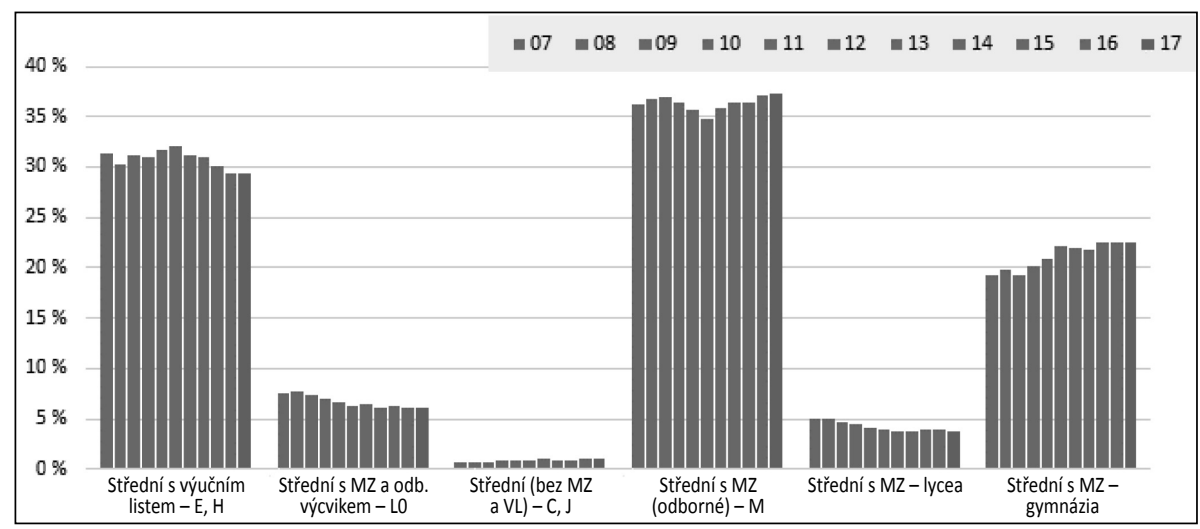

Obr. 2. Vývoj podílu žáků vstupujících do 1 . ročníků středního vzdělávání (u víceletých gymnázií do vyššího stupně), denní studium (zdroj dat: MŠMT, výkonové výkazy řady M8, vlastní propočty)

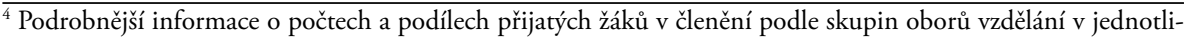
vých kategoriích jsou k dispozici in Vojtěch \& Chamoutová (2018). 
výuční list jako jedna z cest jak reagovat na problémy spojené s neúspěšností některých žáků u maturitní zkoušky.

Podíl žáků vstupujících do gymnaziálního vzdělávání (či přecházejících do jeho vyššího stupně) se po výraznějším nárůstu v letech 2009/2010-2012/2013 $\mathrm{v}$ posledních letech ustálil na hodnotě $22,5 \%$ (což je mimochodem nejméně v Evropě).

Přestože dochází $\mathrm{k}$ pozvolnému poklesu podílu žáků nově přijatých do učebních oborů, je považováno za významné, že se nezastavil nárůst $\mathbf{v}$ technických oborech, ${ }^{4}$ kde oproti minulému školnímu roku došlo $\mathrm{k}$ výraznému nárůstu ve skupině oborů Elektrotechnika (o 0,62 p.b.) a dále v oborech Zpracování dřeva a Strojírenství (o 0,3 a 0,2 p.b.). Naopak největší pokles byl zaznamenán $\mathrm{v}$ gastronomických oborech (-1,3 p.b.).

$V$ maturitních oborech s odborným výcvikem (L0) došlo meziročně $\mathrm{k}$ výraznému poklesu podílu príijímaných ve skupině strojírenských oborů, ovšem tato skupina zaznamenala výjimečně vysoký nárůst v pětiletém období (7,1p.b.).

V klasických maturitních oborech (M) vykazují poměrně výrazný nárůst skupiny Zdravotnictví (1,0 p.b.) a Informační technologie (0,6 p.b.), další, již menší nárůst vykazuje skupina Elektrotechnika (0,3 p.b.). I zde skupina Strojírenství vykazuje meziroční pokles ( 0,7 p.b.), po poměrně velkém nárůstu $\mathrm{v}$ uplynulém pětiletém období. Ve všech kategoriích vzdělání výrazně klesá podíl žáků přijímaných do oborů skupiny Gastronomie, hotelnictví a turismus.
Do počtu žáků jsou zahrnuti i žáci se zdravotním postižením, a to jak žáci škol zř́zených pro žáky se speciálními vzdělávacími potřebami (tzv. speciálních škol), tak žáci se zdravotním postižením integrovaní skupinově nebo individuálně. Podíl žáků se zdravotním postižením je 3,4\% žáků vstupujících do středního vzdělávání po základní škole, v roce 2017/2018 je to 3405 žáků; z nich 2125 vstupuje do různých oborů kategorie $\mathrm{E}$ a 121 do kategorie $\mathrm{H}$, umožňujících dosáhnout výučního listu (hlavně do oborů gastronomických, zemědělských, potravinářských a stavebních), 953 pak do př́pravy v praktické škole a 170 do oborů poskytujících střední vzdělání s maturitní zkouškou.

Ve všech údajích a propočtech jsou zahrnuti i žáci a studenti přijímaní ke studiu $\mathbf{v}$ neveřejných školách (soukromých a církevních). Jejich počet $\mathrm{v}$ denní formě v oborech pro žáky po základním vzdělání je 11974 , což představuje $12 \%$ přijímaných. V oborech odborného vzdělávání je 10204 nově príijatých, $\mathrm{z}$ toho $\mathrm{v}$ oborech poskytujících výuční list 3077 žákủ, v maturitních oborech zahrnujících odborný výcvik 793 žáků a ve studijních oborech poskytujících střední vzdělání s maturitní zkouškou kategorie M 6077 nových žáků.

Není uveden přehled o jiných formách vzdělávání - studiu při zaměstnání; počet žáků v něm je poměrně stabilní, ve školním roce 2017/2018 činí počet nově přijatých 1693 žáků, což představuje $1,7 \%$ počtu žákủ denního vzdělávání. V oborech poskytujících výuční list $(\mathrm{H})$ představuje jejich podíl $1,5 \%$ žáků denního studia, v maturitních oborech odborného vzdělávání $(\mathrm{M})$ 


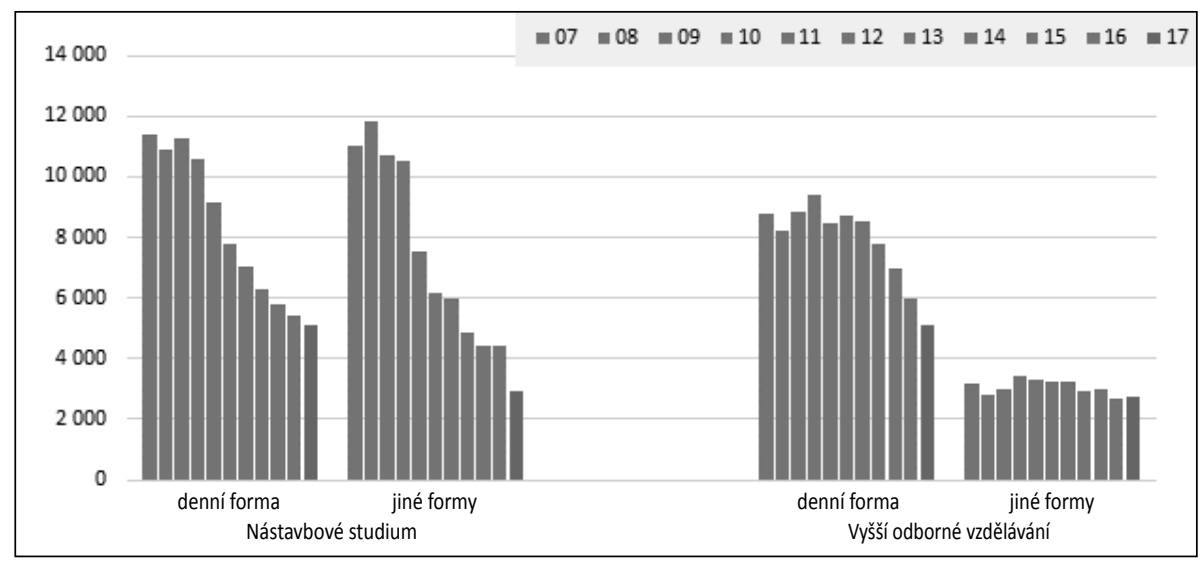

Obr. 3. Vývoj počtů žáků a studentů vstupujících do 1. ročníků nástavbového a vyššího odborného vzdělávání (zdroj dat: MŠMT, výkonové výkazy řady M8, vlastní propočty)

2,7\%, v maturitních oborech s odborným výcvikem (L0) 1,0\% počtu žáků denního vzdělávání. Podíl gymnazistů studujících v jiné než denní formě činí $0,2 \%$.

$\mathrm{V}$ současnosti je již významný i počet žáků vstupujících do zkrácené formy studia, kterou do výše uváděných údajů nezahrnujeme. Toto studium umožňuje vyučeným i maturantům získat ve zkrácené době další výuční list nebo maturantům získat ve zkrácené době maturitu v jiném oboru vzdělání. Do zkráceného studia pro získání výučního listu v roce 2017/2018 vstoupilo 1071 žáků v denní a 586 v jiné formě, do studia k získání druhé maturity vstoupilo 130 žáků v denní a $1496^{5}$ v jiné formě.

$\mathrm{K}$ výraznějšímu vývoji dochází ve struktuře žáků, kteří se připravují v obo- rech navazujících na dříve uvedené kategorie středního vzdělávání, tj. v nástavbovém a vyšším odborném vzdělávání. Protože tyto kategorie vzdělávání nejsou ve vzájemné prrímé vazbě, je na obrázku 3 vyjádřen vývoj pouze $\mathrm{v}$ počtech žáků a studentů nově prrijatých do 1 . ročníků nástavbového a vyššího odborného studia.

Nejvíce žáků bylo přijato do nástavbového studia ve školním roce 2008/2009, a to téměr 12000 žáků v jiných formách a o něco méně v denní formě. Dále se počet přijímaných do nástaveb snižoval, od roku 2011/2012 je zřejmý výrazný pokles. Je to vedle populačního propadu důsledek zavedení nové formy maturitní zkoušky a velké neúspěšnosti absolventů nástaveb u ní. Téměř $75 \%$ přijatých toto studium nedokončí, at již proto, že studium pře-

\footnotetext{
${ }^{5}$ Pro zajímavost uvádíme, že z toho je 1144 žáků, kteří chtějí získat druhou maturitu v oboru Předškolní a mimoškolní pedagogika.
} 
ruší, nebo že neuspěje u maturitní zkoušky, kde je míra jejich neúspěšnosti velmi vysoká. V roce 2017/2018 bylo príijato v denní formě 5110 studujících a v jiných formách 2950 studujících.

Vyšší odborné vzdělávání vykazovalo výrazný rozvoj po roce 1995, kdy nahradilo oblíbené pomaturitní studium. Od roku 2007 do roku 2013 byly počty nově přijímaných $\mathrm{v}$ denním i jiných formách studia víceméně stabilní, po roce 2013 dochází v denní formě každoročně $\mathrm{k}$ výraznému poklesu. To je způsobeno jednak populačním vývojem a také státní maturitou, tedy klesajícím počtem absolventů maturitních oborů, a snadnější dostupností bakalářského studia. $\mathrm{V}$ roce 2017/2018 bylo přijato v denní formě 5131 studujících a $\mathrm{v}$ jiných formách 2747 studujících, převážná část do skupin oborů 53 Zdravotnictví a 75 Pedagogika, učitelství a sociální péče.

\section{VZDĚLANOSTNÍ STRUKTURA V ČLENĚNÍ PODLE KATEGORIÍ VZDĚLÁNÍ V KRAJÍCH ČR}

Sledovat vývoj vzdělanostní struktury v jednotlivých krajích by vyžadovalo velký prostor, zde stačí konstatovat, že $\mathrm{v}$ posledních pěti letech převážně nedochází $\mathrm{k}$ zásadním změnám $\mathrm{v}$ této struktuře $\mathrm{a}$ ta je tedy $\mathrm{v}$ krajích poměrně stabilní.

$\mathrm{K}$ výraznějším nárůstům, pressahujícím 4 p.b., došlo v pětiletém horizontu pouze $\mathrm{v}$ Karlovarském a Pardubickém kraji v nárůstu podílu vyučených a podílu žáků v oborech kategorie $\mathrm{M}$, $\mathrm{k}$ podobnému vývoji došlo v Moravskoslezském kraji v rozsahu kolem 3 p.b. Výraznější poklesy, kolem 3 p.b., byly zaznamenány v maturitních oborech $s$ odborným výcvikem (kategorie L0) v krajích Plzeňském, Karlovarském, Libereckém, Moravskoslezském

Tab. 1. Podíly žáků vstupujících do 1 . ročníků středního vzdělávání (u víceletých gymnázií do vyššího stupně) v krajích ČR, denní studium (zdroj dat: MŠMT, výkonové výkazy řady M8, vlastní propočty)

\begin{tabular}{|c|c|c|c|c|c|c|c|c|c|}
\hline \multirow{2}{*}{$\begin{array}{l}\text { školní rok } \\
2017 / 2018\end{array}$} & \multirow{2}{*}{$\begin{array}{l}\text { Gymná- } \\
\text { zium }\end{array}$} & \multicolumn{3}{|c|}{ Obory vzdělání SOŠ } & \multicolumn{3}{|c|}{ Obory vzdělání SOU, U a OU } & \multirow{2}{*}{$\begin{array}{l}\text { Celkem } \\
\text { G+SOS } \\
+ \text { SOU }\end{array}$} & \multirow{2}{*}{$\begin{array}{l}\mathrm{z} \text { toho } \\
\mathrm{s} \text { matur. }\end{array}$} \\
\hline & & $s$ matur. & $\begin{array}{c}\text { bez } \\
\text { matur. }\end{array}$ & lkem & čbní & $s$ & celkem & & \\
\hline 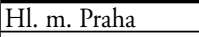 & $8,5 \%$ & $46,3 \%$ & $1,1 \%$ & 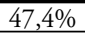 & 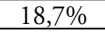 & 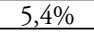 & $24,1 \%$ & $100,0 \%$ & $80,2 \%$ \\
\hline Středočeský k1 & & & $1,7 \%$ & & & & $37,9 \%$ & & \\
\hline & & 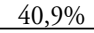 & $0,6 \%$ & & & & $37,6 \%$ & & \\
\hline kraj & & $3,1 \%$ & $2 \%$ & $\frac{5,4}{4}$ & & 9 & $6,7 \%$ & & \\
\hline ský kraj & $2 \%$ & $38,8 \%$ & $1,1 \%$ & $40,0 \%$ & $37,0 \%$ & $4,8 \%$ & $41,9 \%$ & $\%$ & $61,8 \%$ \\
\hline Ústecký kraj & $3 \%$ & $40,3 \%$ & $1,4 \%$ & $41,7 \%$ & $36,2 \%$ & $4,7 \%$ & $40,9 \%$ & $100,0 \%$ & $62,3 \%$ \\
\hline Liber & $1 \%$ & $42,4 \%$ & $0,6 \%$ & $43,0 \%$ & $34,2 \%$ & $4,7 \%$ & $38,9 \%$ & $100,0 \%$ & $65,2 \%$ \\
\hline aradecký k. & $21,1 \%$ & $43,1 \%$ & $1,4 \%$ & $44,4 \%$ & $29,7 \%$ & $4,8 \%$ & $34,4 \%$ & $100,0 \%$ & $69,0 \%$ \\
\hline ký kraj & $19,3 \%$ & $42,0 \%$ & $0,6 \%$ & $42,6 \%$ & $30,9 \%$ & $7,2 \%$ & $38,1 \%$ & $100,0 \%$ & $68,6 \%$ \\
\hline Kraj Vysočina & & $38,9 \%$ & $1,0 \%$ & $39,9 \%$ & & $7,5 \%$ & $37,1 \%$ & $100,0 \%$ &, $3 \%$ \\
\hline & & & $1,0 \%$ & & & $7,1 \%$ & & & $71,1 \%$ \\
\hline ý kraj & & & & & & & & & \\
\hline & & $39,9 \%$ &, $5 \%$ & $40,4 \%$ & & $9,5 \%$ & $34,8 \%$ & & $2 \%$ \\
\hline ezský 1 & $20,7 \%$ & $40,8 \%$ & $1,2 \%$ & $42,0 \%$ & $30,7 \%$ & $6,6 \%$ & $37,3 \%$ & $100,0 \%$ & $68,1 \%$ \\
\hline Česká republika & $22,4 \%$ & $41,0 \%$ & $1,1 \%$ & $42,1 \%$ & $29,3 \%$ & $6,1 \%$ & $35,4 \%$ & $100,0 \%$ & $69,6 \%$ \\
\hline
\end{tabular}


a Olomouckém. V Pardubickém a Karlovarském kraji a v Praze došlo ke snížení podílů príijímaných do gymnázií.

Porovnávání současného stavu a vývoje komplikuje výrazný rozdíl mezi poměry $\mathrm{v}$ krajích a v hlavním městě Praze. Značně odlišný stav v Praze, který je důsledkem odlišné vzdělanostní struktury obyvatel i hospodářství, proto do dalších komentáŕů uvádějících porovnávání Prahu nezahrnujeme.

Do oborů poskytujících vzdělání s výučním listem byl v roce 2017/2018 přijat největší podíl žáků v Karlovarském (37,0 \%) a v Ústeckém kraji (36,2 \%), nejmenší potom ve Zlínském kraji $(24,8 \%$ - zde je to ale kompenzováno vysokým podílem přijatých do oborů $s$ vyučením a maturitou). $\mathrm{V}$ tomto školním roce se v celku ČR podíl žáků v oborech poskytujících výuční list snížil o 0,1 p.b., přičemž největší nárůst byl zaznamenán v Karlovarském (2,0 p.b.) a Královéhradeckém kraji (1,2 p.b.), největší pokles v Kraji Vysočina (3,1 p.b.) a v Plzeňském kraji (1,9 p.b.).

Do oborů kategorie Lo (vyučení $s$ maturitou) byl přijat největší podíl žáků ve Zlínském kraji (9,5\%) a v Kraji Vysočina (7,5 \%), nejmenší podíl ve Středočeském kraji (4,4\%). Trvale výrazně vyšší podíl byl a přetrvává $\mathrm{v}$ moravských krajích a v kraji Plzeňském. Vyšší nárůst vykazují Kraj Vysočina a Pardubický kraj (oba 1,0 p.b.). K výrazným poklesům došlo v krajích Královéhradeckém (0,3 p.b.) a Olomouckém (0,3 p.b.), ČR jako celek vykazuje nárůst 0,1 p.b.

Podíl nově přijatých do čtyřletých gymnázií a pokračujících ve víceletých gymnáziích v tomto roce $\mathrm{v}$ celku ČR mírně poklesl na $22,4 \%$. Největší podíl nově přijatých a přecházejících žáků je v Jihomoravském (25,4\%) a Zlínském kraji $(24,8 \%)$, nejmenší v krajích Ústeckém (17,3\%) a Libereckém (18,1\%). Největší úbytek vykazuje Pardubický kraj (1,1 p.b.), nejvyšší nárůst pak Liberecký kraj (1,1 p.b.). Opět připomínáme, že do srovnání nezahrnujeme hlavní město Prahu.

$\mathrm{V}$ maturitních oborech kategorie M byl zaznamenán nejvyšší podíl nově přijatých žáků v krajích Královéhradeckém a Plzeňském (shodně 43,1\%), nejmenší ve Středočeském kraji (37,6\%), což je ale ovlivněno dojížd'kou mnoha žáků do Prahy, a v Olomouckém kraji (38,2 \%). Podíl nově přijatých vykazuje nejvýraznější pokles $\mathrm{v}$ Jihočeském kraji (0,9 p.b.), nejvyšší nárůst je pak v Kraji Vysočina (2,1 p.b.). V ČR jako celku zůstal podíl v této kategorii nezměněn.

Do maturitních oborů jako celku je přijímán nejvyšší podíl žáků ve Zlínském $(74,2 \%)$ a Jihomoravském kraji (71,1 \%), nejnižší v Karlovarském kraji (61,8 \%). V tomto komentáři ovšem neporovnáváme Prahu, kde je podíl přijatých do maturitních oborů nejvyšší $(80,2 \%)$.

VÝVOJ VZDĚLANOSTNÍ STRUKTURY ABSOLVENTU゚ A JEJICH PŘECHOD NA TRH PRÁCE

$\mathrm{V}$ předchozí části bylo poměrně podrobně popsáno rozložení populace prochá- 


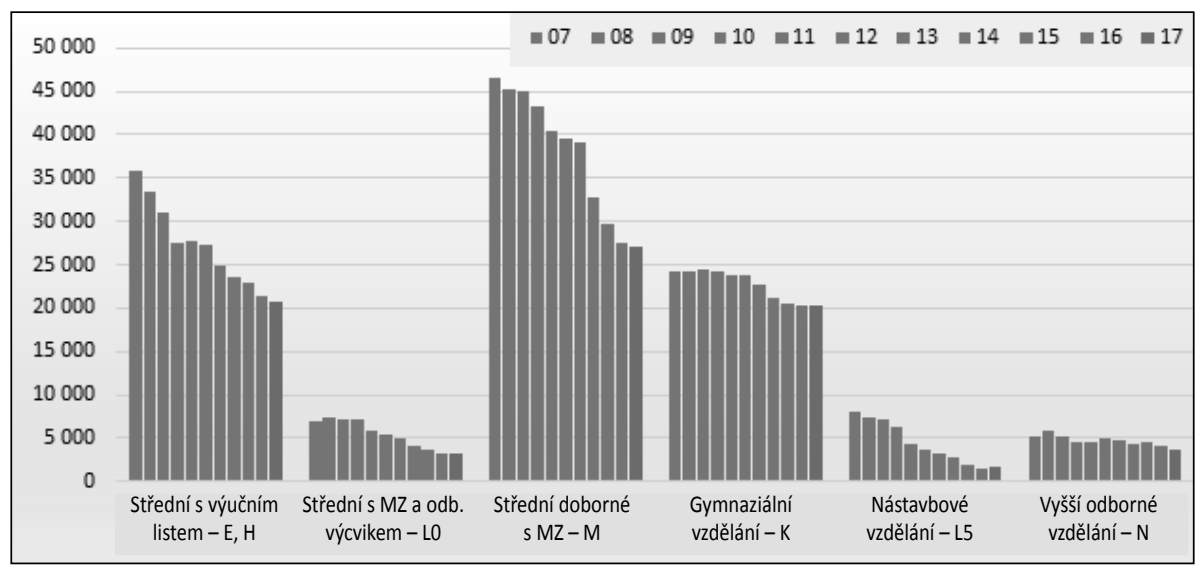

Obr. 4. PVývoj počtu absolventů, kteří v letech 2006-2017 ukončili vzdělávání (zdroj dat: MŠMT, výkonové výkazy řady $\mathrm{M} 8$, vlastní propočty)

zející středním vzděláváním v okamžiku, kdy do něj vstupuje (a kdy je také přehlednější posuzovat podíly žáků pro jednotlivé kategorie). $\mathrm{Na}$ výstupu, tedy z hlediska absolventů, je jejich podíl na struktuře podle kategorií vzdělání mnohem komplikovanější. Je třeba vzít $\mathrm{v}$ úvahu různou délku studia, rozdílný věk ukončování studia, přesuny $\mathrm{v}$ jeho průběhu, předčasné odchody ze vzdělávání a odklady, přestupy a opakované vstupy i do vyšších ročníků způsobené neúspěšnosti žáků u maturitních zkoušek.

Vývoj počtu absolventů $v$ jednotlivých kategoriích vzdělání je skutečně znepokojivý, zejména proto, že není ovlivněn pouze vývojem populace a tedy počtem přijímaných žáků před několika lety, ale v posledních letech i neúspěšností žáků u maturitních zkoušek nebo předčasnými odchody ze vzdělávání $\mathrm{z}$ jiných důvodů. Někteř́ žáci sice maturitní zkoušku složí $\mathrm{v}$ pozděǰsím termínu, někteří přejdou do učebního oboru, nezanedbatelná část však odejde ze vzdělávání. Tito mladí lidé pak na trhu práce představují pracovní sílu se základním vzděláním, $\mathrm{v}$ počtech absolventů se středním vzděláním se neobjeví. Také u učebních oborů je zřejmý nárůst předčasných odchodů. Vzhledem $\mathrm{k}$ současnému nedostatku pracovníků na trhu práce lze totiž nalézt pracovní uplatnění i bez výučního listu.

Nárůst počtu mladých lidí bez získané kvalifikace, tedy pouze se základním vzděláním, je nežádoucím jevem, zejména pokud absolvovali čtyři či více let vzdělávání. Problémem pro ně bude získat bez certifikátu o kvalifikaci perspektivní zaměstnání, i když odbornou problematiku dobře zvládli a byli by stejně kvalitními odborníky, jako byli před lety jejich předchůdci.

Pokles počtu absolventů $\mathrm{v}$ průběhu posledních pěti let nejvíce postihuje maturitní obory poskytující odborné vzdělá- 
ní (kategorie M a L0), ještě více pak obory nástavbové (kategorie L5). Méně výrazný je pokles v učebních oborech (kategorie E a $\mathrm{H})$. V oborech gymnaziálního vzdělávání je dán spíše populačním poklesem.

\section{ZÁVĚR}

Vzdělanostní struktura žáků nově přijímaných do středního a vyššího vzdělávání i jeho absolventů je trvale středem zájmu zaměstnavatelů a jejich reprezentantů. Úroveň vzdělání je kritérium hrající důležitou roli při rozhodování dětí a jejich rodičů o budoucí profesi a $\mathrm{k}$ ní vedoucí vzdělávací dráze. Data jsou důležitou oporou pro hlavní aktéry vzdělávací politiky i pro naplňování krokủ strategie rozvoje ekonomiky v kontextu s aktivitami Společnost 4.0.

$\mathrm{Z}$ údajů uvedených $\mathrm{v}$ textu je patrné, že základním problémem $\mathbf{v}$ našem středním školství není struktura vzdělanosti, ale výrazný pokles počtu žáků $v$ populačních ročnících. Zejména $v$ pohledu na strukturu nově přijímaných je zřejmé, že nedochází $\mathrm{k}$ výrazným změnám struktury vzdělanostní úrovně. Podíl gymnazistů narůstá pouze nepatrně, zastoupení ostatních kategorií vzdělání je dlouhodobě stabilní.

Porovnání se strukturou středoškolských absolventů v jiných evropských zemích ukazuje, že současná struktura vycházejících absolventů v ČR je zcela unikátní z pohledu nejnižšího podílu žáků gymnaziálního vzdělávání a nejvyššího podílu žáků připravovaných $\mathrm{v}$ technických oborech (skupiny Technické obory, výroba a stavebnictví, viz Vojtěch \& Chamoutová, 2017).

Dlouhodobý pokles populačních ročníků představuje již mnoho let problém jak pro střední školy, tak pro zaměstnavatele. Naplněnost odborných škol se ani ve školním roce 2018/2019 zásadně nezmění, v celkových počtech žáků bude pokles ještě pokračovat a výrazné zlepšení se projeví až po roce 2020. Ve středním školství tak nadále výrazně přebývají kapacity, klesá velikost tříd a počty žáků na učitele, což je, vzhledem ke značnému počtu oborů vzdělání, problémem i z hlediska zajištění kvalitní výuky a vybavení škol. Je potřebné si uvědomit, že v málo atraktivních oborech nejde o velikosti trríd $\mathrm{v}$ řádu desítek žáků, ale mnohde je zajištována výuka $\mathrm{v}$ oborech pro skupiny tří až šesti žáků. $V$ některých krajích začala optimalizace vzdělávací nabídky. Školám by z ekonomického pohledu mohl pomoci nový způsob financování. Nedostatek žáků a malá naplněnost škol však zůstane i nadále problémem.

Vzhledem k tomu, že počty absolventů se budou dále snižovat, budou se zaměstnavatelé i nadále potýkat $s$ nedostatkem pracovní síly, což se nepríznivě projevuje právě v období ekonomického růstu. I když je do terciárního studia každoročně přijímáno asi $55 \%$ absolventů maturitních oborů odborného vzdělávání, jejich poměrně vysoká neúspěšnost a předčasné ukončení studia asi $30 \%$ z nich privede zpět na trh práce.

Obavy z neúspěšnosti u maturitní zkoušky mají vliv na snížení podílu těch absolventů učebních oborů, kte- 
ří přecházejí do nástavbového studia, avšak ani tento fakt nemá na poměr nabídky a poptávky na trhu práce významný dopad.

Zdůrazňování potřebnosti a uplatnitelnosti vyučených absolventů i podpora formou stipendií či jiných výhod, pořádání propagačních akcí apod. ovlivňuje žáky a jejich rodiče a směruje větší podíl nově přijímaných do nejžádanějších, technických učebních oborů. I když celkově podíl přijímaných do učebních oborů opět nepatrně poklesl, podíl přijatých do tolik potřebných strojírenských a elektrotechnických oborů narostl.

Současně se domníváme, že podíl žáků $\mathrm{v}$ učebních oborech je odpovídající budoucím potřebám naší společnosti. Rozvinuté střední odborné vzdělávání $s$ maturitou zahrnující přes $40 \%$ populačního ročníku připravuje pracovníky, kteří se rovněž mohou uplatnit $\mathrm{v}$ dělnických pozicích odpovídajících vývoji technologií, kde již dnes nejsou rozhodující pouze manuální dovednosti, ale mnohdy převažuje potřeba dovedností intelektuálních.

\section{LITERATURA}

Chamoutová, D., Vojtěch, J., \& Chomová, P. (2017). Analýza realizované vzdèlávací nabidky střednich škol. Praha: NÚV. Dostupné z www.infoabsolvent.cz.

Chomová, P. (Ed.). (2018). Uplatnéní absolventů škol na trhu práce - 2017. Praha: NÚV. Dostupné z www.infoabsolvent.cz.

Kleňha, D., \& Vojtěch, J. (2018). Přechod absolventů střednich škol do terciárního vzdèláváni2017/18. Praha: NÚV. Dostupné z www.infoabsolvent.cz.

Nařizení vlády č. 211/2010 Sb., o soustavě oborů vzděláni v základnim, středním a vy̌šsim odborném vzdělávání.

NÚV (2018a). Informačni systém o uplatnéní absolventů škol na trhu práce. (Online). Dostupné z www.infoabsolvent.cz.

NÚV (2018b). Nově prijatí žáci a absolventi v krajich ČR. (Online). Dostupné z www.nuv.cz. Průcha, J. (Ed.). (2009). Pedagogická encyklopedie. Praha: Portál.

Vojtěch, J., \& Chamoutová, D. (2017). Vývoj vzdělanostní a oborové struktury žáků a studenti̊ ve střednim a vyšsím odborném vzděláváni $v \check{C} R$ a v krajich $\check{C} R$ a postaveni mladých lidí na trhu práce ve srovnání se stavem v Evropské unii - 2016/17. Praha, NÚV. Dostupné $\mathrm{z}$ www.infoabsolvent.cz.

Vojtěch, J., \& Chamoutová, D. (2018). Vývoj vzdělanostni a oborové struktury žáků a studentů ve strednim a vyšsím odborném vzděláváni $v \check{C} R$ a v krajich $\check{C} R$ a postaveni mladých lidí na trhu práce ve srovnání se stavem v Evropské unii - 2017/18. Praha, NÚV. Dostupné $\mathrm{z}$ www.infoabsolvent.cz.

Zákon č. 561/2004 Sb., o predškolním, základním, středním, vyššim odborném a jiném vzděláváni (školský zákon). 
Ing. Jiři Vojtèch,

Národni ústav provzdèláváni; e-mail: jiri.vojtech@nuv.cz

Mgr. Martin Úlovec,

Národni ústav pro vzdèláváni; e-mail: martin.ulovec@nuv.cz

\section{VOJTĚCH, J., ÚLOVEC, M. Development of Educational Structure of Students in Upper Secondary and Post-Secondary Non-Tertiary Education}

Abstract: The overview study is focused on the topic of the educational structure of both students and school leavers of upper secondary and post-secondary non-tertiary education. It describes the educational structure development and explains the changes of percentage of students entering into upper secondary and post-secondary education. In order to describe the educational structure and its development, the study uses relative frequencies, which are, from the point of view catching the system dynamics and changes, more relevant than absolute frequencies. The starting point is the population development in the Czech Republic and its relation to the development of the distribution of students into categories of education. Besides the national level, the study presents the issue in regional perspective comparing different regions from the point of view of the development of the distribution of different categories of education. The study then deals with the development of the school leavers' number and related problems. A comparison with other European countries is valuable for the conception of the educational policy. It shows that in the Czech Republic there is the highest number of students in technical fields of study and the lowest number in upper secondary grammar schools. The conclusion deals with the problem of the long-term demographic decline. Even if the distribution of students into different categories of education is relatively stable, the impact of the demographic decline on the number of school leavers is that the employers' demand for qualified manpower is not met. The proportion of school leavers in different categories of education is also influenced by other factors, first of all the premature leavings of education. They present a great risk from the social cohesion point of view. Young people, who have not achieved any qualification and have only primary education, are in danger of a repeated long-term unemployment with all the negative consequences in the area of social pathology phenomena.

Keywords: educational structure, categories of education, apprenticeship education, school leaving examination in vocational education, school leaving examination including professional training, secondary general education, further education, upper secondary education, demographic decline, skilled workforce. 